\title{
Haptic judgment of the Müller-Lyer illusion by subjects of different ages
}

\section{RAY OVER \\ UNIVERSITY OF OTAGO, NEW ZEALAND}

Age differences have been commonly found in the magnitude of the visual illusion obtained with the Müller-Lyer illusion. The present experiment has examined haptic (tactualkinesthetic) judgments of this figure by Ss of different ages. Young children, older children, and adults did not differ in amount of haptic illusion. The bearing of this finding on Piaget's analysis of age differences in visual illusion is discussed.

An illusion is found with haptic as well as visual inspection of the Müller-Lyer figure (Révész, 1953). During haptic inspection, $S$ is blindfolded and is required to move his finger over the raised outlines of the figure. Available data suggest that similar processes underlie illusions in the two modalities (Over, 1967). The present experiment further examines the relationship between visual and haptic judgments of illusion figures by considering whether the decrement in magnitude of visual illusion characteristically found across age groups with the Müller-Lyer figure (see Piaget, 1961; Wohlwill, 1960) is also obtained with haptic judgment of this figure.

Method

Sixteen children (eight male, eight female) at each of four age groups (mean ages 7-2, 9-3, 11-2, 14-9), as well as 16 adults (mean age 21-5), were tested. The children were selected from local schools and were considered to be of average ability by their teachers. A group of children of age 5-0 were also to be tested. Preliminary testing indicated, however, that it was not possible to instruct children of this age to make haptic judgments.

The Muller-Lyer figure consisted of three $60^{\circ}$ arrowheads, each $9 \mathrm{~cm}$ long and made of wire $1.1 \mathrm{~cm}$ in diameter, mounted on a wooden rod $28.5 \mathrm{~cm}$ long and $1.5 \mathrm{~cm}$ wide. The extreme arrowheads were fixed in position $20.6 \mathrm{~cm}$ apart and the center arrowhead could be moved along the rod by $\mathrm{S}$.

The Ss were not blindfolded but were required to reach beneath a curtained frame to touch the figure with the index finger of the right hand. Each $S$ was given one practice trial and five test trials. On the practice trial S's finger was initially moved over the arrowheads and along the rod by $\mathrm{E}$, and $\mathrm{S}$ was told that his task was to adjust the movable piece of wire so that its center was exactly midway between the two fixed pieces of wire. The $\mathrm{S}$ was allowed to move his finger from arrowhead to arrowhead as many times as he wished, but every time he touched an arrowhead he was required to trace over its full extent. No information was given to $S$ about the accuracy of his settings. For half of the Ss the outward pointing fixed arrowhead was on S's left on all trials, and for the other half on S's right. Half of the Ss in each group made judgments with the movable arrowhead initially set $2.7 \mathrm{~cm}$ to the left of the midposition, and half $2.7 \mathrm{~cm}$ to the right of the midposition. Results

The mean setting (distance in $\mathrm{cm}$ from the inward pointing arrowhead) of the center arrowhead by each age group is shown in Table 1. If haptic inspection did not produce any illusion the center arrowhead would be set by $\mathrm{Ss}$ in the midposition $(10.3 \mathrm{~cm}$ from each fixed arrowhead). At each age group mean setting differs significantly $(p<.01)$ from physical equality. An analysis of variance indicates that differences in mean illusion between age groups are not significant $(F=1.69, d f=4 / 75, p>.05)$. The standard deviation of his five settings was also calculated for each $\mathrm{S}$, and mean intrasubject variability is shown for each age group in Table 1. These means differ significantly $(F=6.66, \mathrm{df}=4 / 75, \mathrm{p}<.01)$, and comparisons using Duncan's New Multiple Range test (Edwards, 1963) indicate that Ss of age 14-9 and 21-5 were less variable over their five test trials than Ss of age 7-2 and 9-3. The Ss of age 11-2 were less variable than Ss of age 9-3. At no age level did mean illusion on the last of the five trials differ significantly from mean illusion on the first trial. Thus, the greater intrasubject variability found with younger Ss does not represent initial inaccuracy followed by a trend to greater accuracy.

Discussion

The present experiment has shown that age differences in amount of illusion do not occur with haptic inspection of the Müller-Lyer figure. Age differences have commonly been found with visual judgment of this figure; a larger visual illusion is obtained with young children than older children and adults (see Piaget, 1961; Wohlwill, 1960). The present data thus suggest that age differences in amount of visual illusion are dependent on processes which

Table 1 Mean setting and intra-S variability at different age levels

\begin{tabular}{lccccc}
\hline & \multicolumn{5}{c}{ Age Levels } \\
& $7-2$ & $9-3$ & $11-2$ & 149 & $21-5$ \\
\hline Mean setting & 8.55 & 8.17 & 8.81 & 8.80 & 8.54 \\
S.D. & 2.38 & 2.71 & 2.30 & 2.12 & 1.96 \\
Mean intra-S & 1.68 & 1.75 & 1.18 & 0.93 & 1.10 \\
$\begin{array}{l}\text { variability } \\
\text { S.D. }\end{array}$ & 2.80 & 2.48 & 2.17 & 1.30 & 1.89 \\
\hline
\end{tabular}


are specific to vision rather than on processes common to the visual and haptic modalities. In his treatment of illusions, Piaget (1961) has offered a detailed analysis of age differences in visual illusion. The extent to which this theory is applicable to haptic judgment of illusion figures can be briefly considered.

Piaget (1961) has attributed the perceptual distortion found with visual judgment of an illusion figure to overestimation of parts of the figure which receive the greatest density of fixations during inspection relative to parts which receive fewest fixations. The smaller illusion found for adults is said to arise because adults sample the total figure more evenly and widely during inspection, and thus make less relative error, than children. Although Plaget has not made explicit reference to haptic judgment of illusion figures, he has indicated (Piaget, 1961) that young children adopt a passive haptic, as well as visual, method of inspection of objects in their environment. In these terms similar age differences in amount of illusion might be expected for judgment in the two modalities.

There is, however, one important difference between visual and haptic inspection of an illusion figure. During visual inspection stimulation from the total figure is distributed across the receptor surface at the one time, but with haptic inspection the total figure can be experienced only by successive sampling of information from different parts of the figure by a process akin to fixation. Although more time can be spent on haptic inspection of some parts of a figure relative to others, it is probable that the operations involved in inspecting the whole figure generate a relatively uniform method of sampling information by Ss of different ages. All Ss, for example, were required to trace over the full length of an arrowhead when part was touched. In terms of Piaget's theory, the enforced widespread sampling from the figure during haptic inspection would lead to young children showing less haptic illusion than visual illusion and to an absence of age differences in amount of haptic illusion.

References

EDWARDS, A. L. Experimental design in psychological research. New York: Holt, Rinehart \& Winston, 1963.

OVER, R. Haptic illusions and inappropriate constancy scaling. Nature, $1967,214,629$.

PIAGET, J. Les mécanismes perceptifs. Paris: Presses Universitaires de France, 1961.

RÉVÉSZ, G. Lassen sich die bekannten geometrisch-optischen Täuschungen auch im haptischen Gebiet nachweisen. J. Psychol, Psychother., 1953, 1, 464-478.

WOHLWILL, J. F. Developmental studies in perception. Psychol Bulh, $1960,57,249-288$.

Note

1. This study was supported by a grant from the New Zealand University Grants Committee. The author wishes to thank Joan Over for her assistance in collecting the data. 